\title{
PENGEMBANGAN PROTOTIPE EGG BOILER SEBAGAI MEDIA PEMBELAJARAN PRAKARYA DAN KEWIRAUSAHAAN UNTUK MATERI TEKNOLOGI TEPAT GUNA KELAS XI MIA SMA NEGERI 4 SINGARAJA TAHUN AJARAN 2016/2017
}

\author{
Kadek Indra Kusuma Harta ${ }^{1}$, I Gede Nurhayata ${ }^{2}$, Luh Krisnawati ${ }^{3}$ \\ ${ }^{1}$ Fakultas Teknik dan Kejuruan, Universitas Pendidikan Ganesha \\ e-mail: kusumahartakadek@gmail.com \\ ${ }^{2}$ Fakultas Teknik dan Kejuruan, Universitas Pendidikan Ganesha \\ e-mail: gede.nurhayata@undiksha.ac.id \\ ${ }^{3}$ Fakultas Teknik dan Kejuruan, Universitas Pendidikan Ganesha \\ e-mail: luh.krisnawati@undiksha.ac.id
}

\begin{abstract}
Abstrak
Penelitian ini bertujuan untuk mengembangkan Prototipe Egg Boiler (Pengkukus Telur Otomatis) sebagai media pembelajaran untuk mata pelajaran Prakarya dan Kewirausahaan pada materi Teknologi Tepat Guna di Kelas XI MIA SMA Negeri 4 Singaraja. Penelitian ini dilakukan dengan menggunakan metode Penelitian dan Pengembangan dalam bidang pendidikan. Hasil uji validasi ahli media memperoleh skor sebesar 0,75 dalam kategori tinggi. Uji validasi isi dengan nilai sebesar 0,81 dalam kategori sangat tinggi. Sedangkan hasil uji coba perorangan dengan nilai sebesar 0.93 , uji coba kelompok kecil dengan nilai sebesar 0.71 , dan uji coba lapangan dengan nilai sebesar 0.82 . Pada uji coba lapangan juga dilakukan dengan menganalisis nilai dari kegiatan praktikum, nilai yang diperoleh 87.4 dikategorikan dengan hasil belajar tinggi. Dari hasil nilai pre-test dan post-test tersebut secara keseluruhan mengalami peningkatan. Sehingga Pototipe Egg Boiler yang telah dikembangkan sangat membantu siswa dalam memahami materi dan praktikum mata pelajaran Prakarya dan Kewirausahaan untuk materi Teknologi Tepat Guna di Kelas XI MIA SMA Negeri 4 Singaraja.
\end{abstract}

Kata-kata kunci: Penelitian dan Pengembangan, Prototipe Egg Boiler, Teknologi Tepat Guna

\begin{abstract}
This study aims to develop Prototype Egg Boiler (Automatic Egg Steam) as a medium of learning for the subject of Workshop and Entrepreneurship on the Materials of Appropriate Technology in Class XI MIA SMA Negeri 4 Singaraja. This research was conducted by using the method of Research and Development in the field of education. The expert media of validation test results obtained a score of 0.75 in the high category. Test content validation with a value of 0.81 in very high category. While the results of individual trials with a value of 0.93 , small group testing with a value of 0.71 , and field trials with a value of 0.82 . In field trials also conducted by analyzing the value of practical activities, the value obtained 87.4 is categorized with high learning outcomes. From the results of the pre-test and post-test value as a whole has increased. So Pototipe Egg Boiler that has been developed to help students in understanding materials and practical subjects of Workshop and Entrepreneurship for Materials Technology Appropriate in Class XI MIA SMA Negeri 4 Singaraja.
\end{abstract}

Keywords: Research and Development, Prototype Egg Boiler, Appropriate Technology 


\section{PENDAHULUAN}

Pada saat ini, kita hidup di zaman globalisasi atau bisa juga disebut zaman modernisasi. Modernisasi sendiri dalam ilmu sosial merujuk pada bentuk transformasi dari keadaan yang kurang maju atau kurang berkembang ke arah yang lebih baik dengan harapan kehidupan masyarakat akan menjadi lebih baik. Modernisasi mencakup banyak bidang, contohnya dalam bidang ilmu pengetahuan dan teknologi. Zaman modernisasi seperti sekarang, manusia sangat bergantung pada teknologi. Hal ini membuat teknologi menjadi kebutuhan dasar setiap orang. Dari orang tua hingga anak muda, para ahli hingga orang awam pun menggunakan teknologi dalam berbagai aspek kehidupannya. Kebutuhan manusia akan teknologi juga didukung dengan perkembangan ilmu pengetahuan dan teknologi yang sangat pesat. Perkembangan teknologi berkembang secara drastis dan terus berevolusi hingga sekarang dan semakin mendunia.

Teknologi juga sangat berpengaruh besar dalam dunia pendidikan. Kemajuan teknologi diiringi dengan kemajuan pendidikan khususnya pendidikan di Indonesia. Teknologi dalam pendidikan merupakan suatu bagian dari konsep teknologi pendidikan baik berupa media untuk memperlancar kegiatan proses belajar mengajar. Dalam proses belajar mengajar seorang guru akan menggunakan keahliannya dalam menstranfer ilmu kepada siswanya. Dalam proses tersebut seorang pendidikan akan merasa sulit jika menyampaikan materi atau teori yang sifatnya sulit dimengerti dengan sebuah kata kata dan seorang pendidik haruslah menyiapkan suatu media pembelajaran yang berkaitan dengan materi atau teori yang diajarkan. Agar nantinya proses pembelajaran bisa berjalan dengan baik dan siswa bisa menyengerti dengan sangat jelas dengan materi atau teori yang diajarkan. Sekarang ini bukan hanya di perguruan tinggi saja, tetapi di Sekolah dari tingkat Sekolah Dasar sampai Sekolah Menengah Atas/Kejuruan pun disetiap kelas sudah disediakan sebuah Layar dan LCD Proyektor. Dimana fungsi alat tersebut untuk menampilakan suatu tayangan yang berasal dari input baik itu sebuah laptop. Yang ditayangkan baik itu sebuah video, gambar maupun suatu file tertentu. Hal tersebut sesuai dengan tuntutan Kurikulum 2013, dimana seorang guru diperbolehkan untuk membawa media pembelajaran yang dibantu dengan laptop. Baik itu dari laptop menampilkan sebuah persentasi untuk mempermudah guru untuk menjelaskan suatu materi. Itu merupakan penggunaan media pembelajaran seiring kemajuan teknologi.

Jadi pendidikan memiliki peranan utama demi menghasilkan suatu sumber daya manusia yang baik dan berkualitas. Yang nantinya bisa memajukan negaranya sendiri yaitu Negara Indonesia. Pendidikan merupakan sebagai usaha sadar dan terencana untuk mewujudkan suasana belajar dan proses pembelajaran untuk peserta didik secara aktif mengembangkan potensi dirinya untuk memiliki kekuatan spiritual keagamaan, pengendalian diri, kepribadian, kecerdasan, akhlak mulia, serta keterampilan yang diperlukan dirinya dan masyarakat. Pendidikan dapat diartikan sebagai usaha sadar dan sistematis untuk mencapai taraf hidup atau untuk kemajuan lebih baik. Secara sederhana, pengertian pendidikan adalah proses pembelajaran bagi peserta didik untuk dapat mengerti, paham, dan membuat manusia lebih kritis dalam berpikir.

SMA Negeri 4 Singaraja merupakan suatu Sekolah Menengah Atas Negeri yang ada ditengah-tengah kota Singaraja, selain itu Foursma atau sebuatan lain dari SMA Negeri 4 Singaraja merupakan salah satu sekolah terfavorit di Kabupaten Buleleng. Selain itu, Foursma merupakan sekolah yang menjujung tinggi dari segi non akademi baik dari bidang olahraga maupun dari bidang seni. Di SMA Negeri 4 Singaraja penulis melaksanakan Praktikum PPL-Real Dan diberikan tugas dan kepercayaan untuk mengisi mata pelajaran Prakarya dan Kewirausahaan (Rekayasa) di kelas XI MIA. Penulis melaksanakan kegiatan PPL-Real ini selama 3 bulan. Selama melaksanakan kegiatan PPL-Real penulis menemukan banyak kendala yang dihadapi, khususnya dalam bidang menyampaikan suatu materi 
atau proses pembelajaran. Sesuai dengan Standar Kompetensi yang telah ditentukan, dimana siswa akan dituntut agar bisa membuat sesuatu projek yang akan digunakan sebagai modal untuk berwirausaha. Projek yang dibuat sesuai dengan materi pokok yang didapatkan pada semester tersebut. Untuk semester genap nanti materi pokok yang akan dibahas yaitu Teknologi Tepat Guna. Jadi karena siswa di SMA Negeri 4 Singaraja kebanyakan memiliki kemampuan dasar di bidang elektronika dan untuk membuat suatu projek, rasa itu sangat membebani siswa tersebut. Selain itu tidak adanya media pembelajaran disekolah yang membantu siswa dalam praktikum maupun memahami suatu materi.

Untuk menjadi seorang guru yang profesionalisme bukan hanya bisa dilihat dari kemampuan mengembangkan ilmu pengetahuan guru tersebut, tetapi yang lebih penting yaitu pada kemampuannya untuk melaksanakan proses pembelajaran yang menarik dan bermakna bagi siswanya. Upaya yang harus guru lakukan untuk mendukung proses pembelajaran yang menarik, yaitu dengan melakukan inovasi berbeda dalam pembelajaran. Salah satu inovasi pembelajaran adalah media praktikum. Banyaknya media praktikum yang mendukung proses pembelajaran yang mendukung kegiatan praktikum salah satunya adalah Prototipe.

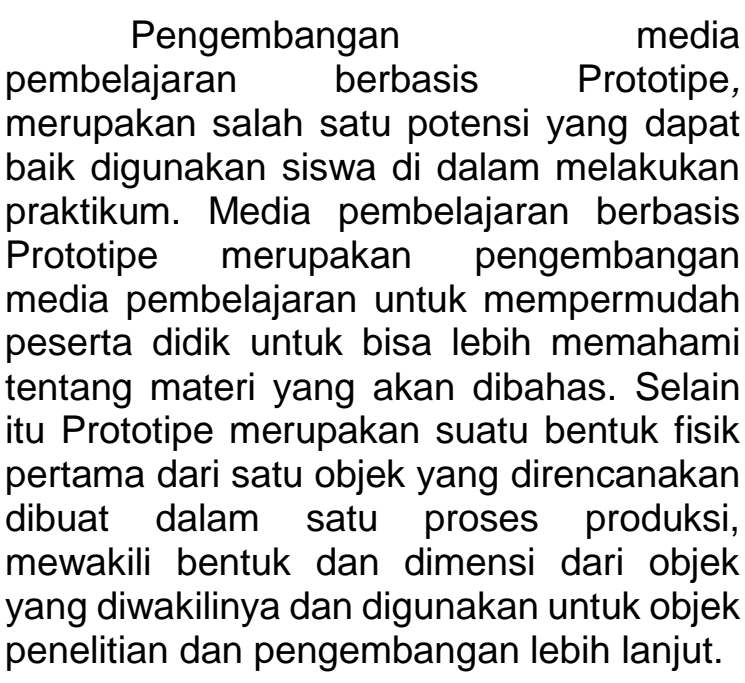

Hal yang menarik perhatian penulis ialah untuk standar kompetensi tersebut belum memiliki media pembelajaran dalam bentuk Prototipe untuk membantu pemahaman siswa. Teknologi Tepat Guna akan menjadi materi pembelajaran yang menarik dan mudah dipahami, jika disajikan dengan suatu media yang praktis dan fleksibel. Penulis akan membuat salah satu contoh produk Teknologi Tepat Guna yaitu Egg Boiler atau pengkukus telur otomatis. Dan Egg Boiler tersebut akan dibuat suatu Prototipe.

Berdasarkan hasil temuan di atas, maka penulis tertarik untuk melakukan penelitian yang berjudul "Pengembangan Prototipe Egg Boiler Sebagai Media Pembelajaran Pendukung Pembelajaran Pada Mata Pelajaran Prakarya dan Kewirausahaan Untuk Materi Teknologi Tepat Guna Kelas XI MIA SMA Negeri 4 Singaraja Tahun Ajaran 2016/2017". Egg Boiler akan dikembangkan sebagai alat peraga dalam bentuk Prototipe. Untuk memudahkan siswa dalam memahami salah satu contoh produk Teknologi Tepat Guna pada mata pelajaran Prakarya dan Kewirausahaan di kelas XI MIA SMA Negeri 4 Singaraja.

Berdasarkan permasalahan diatas maka tujuan dari penelitian ini adalah untuk menghasilkan Prototipe Egg Boiler sebagai media pembelajaran pendukung pembelajaran pada mata pelajaran Prakarya dan Kewirausahaan untuk materi Teknologi Tepat Guna kelas XI MIA SMA Negeri 4 Singaraja

Penelitian dan pengembangan merupakan konsep yang relatife masih baru di bidang pendidikan. IImu pengetahuan dapat dianggap sebagai strategi mencari pengetahuan yang kurang lebih bersifat abstrak yang dinamakan teori. Sedangkan pengembangan adalah penerapan pengetahuan yang terorganisasi untuk membantu memecahkan masalah dalam masyarakat termasuk di bidang pendidikan. Sebuah pertanyaan menarik yang muncul bagi para peneliti, mengingat saat ini penelitian pengembangan menjadi suatu metode penelitaian yang cukup popular dan banyak dipilih sebagai metode penelitian dalam segala bidang kajian, termasuk dalam dunia pendidikan. Penelitian merupakan kegiatan pengumpulan, pengolahan, analisis, dan penyajian data 
yang dilakukan secara sistematis dan objektif untuk memecahkan suatu persoalan atau ingin menguji suatu hipotesis untuk mengembangkan prinsipprinsip umum, sedangkan pengembangan adalah proses atau cara yang dilakukan untuk mengembangkan sesuatu menjadi baik atau sempurna. Kalau arti penelitian dan arti pengembangan dikaitkan menjadi satu kata utuh yaitu penelitian dan pengembangan, maka dapat diartikan sebagai "kegiatan pengumpulan, pengolahan, analisis, dan penyajian data yang dilakukan secara sistematis dan objektif yang disertai dengan kegiatan pengembangan sebuah produk untuk memecahkan suatu persoalan yang dihadapi.

\section{Prototipe}

Menurut Raymond McLeod (dalam Yudo Nugroho: 2010), Prototipe didefinisikan sebagai alat yang memberikan ide bagi pembuat maupun pemakai potensial tentang cara sistem berfungsi dalam bentuk lengkapnya, dan proses untuk menghasilkan sebuah Prototipe disebut prototyping. Sedangkan menurut Achmad Rasul (dalam Yudo Nugroho: 2010), prototyping merupakan salah satu metode pengembangan perangat lunak yang banyak digunakan. Dengan metode prototyping ini pengembang dan pelanggan dapat saling berinteraksi selama proses pembuatan sistem. Dalam tulisannya, Achmad Rasul mengungkapkan bahwa dalam dunia bisnis saat ini sering terjadi kesalah pahaman antara seorang pelanggan dan pengembang. Biasanya, seorang pelanggan dalam memberi masukan hanya sebatas definisi secara umum dari apa yang mereka kehendaki saja tanpa menyebutkan secara detail output apa saja yang dibutuhkan. Sebaliknya, disisi yang lain, pengembang kurang memperhatikan efesiensi algoritma, kemampuan sistem operasi dan interface yang menghubungkan manusia dan komputer. Untuk mengatasi masalah ini, baik pihak pelanggan maupun pihak pengembang harus mampu bekerjasama. Hal ini bertujuan agar pengembang dapat mengetahui dengan benar apa yang diinginkan pelanggan dengan tidak mengesampingkan segi-segi teknis. Dan pelanggan akan mengetahui proses-proses dalam menyelesaikan sistem yang diinginkan. Dengan demikian akan menghasilkan suatu prototipe yang mana akan dihilangkan sebagian atau seluruhnya dan perangkat lunak aktual direkayasa dengan kualitas dan implementasi yang sudah ditentukan oleh kedua belah pihak. Metode prototipe sendiri saat ini merupakan suatu paradigma baru dalam pengembangan sistem informasi. Hal ini tidak hanya sekedar suatu evolusi dari metode pengembangan sistem informasi yang sudah ada, tetapi sekaligus merupakan revolusi dalam pengembangan sistem informasi manajemen.

\section{Egg Boiler}

Egg Boiler atau dalam Bahasa Indonesia disebut Pengkukus Telur Otomatis. Pada dasarnya untuk membuat telur matang dengan baik adalah direbus dengan mengunakan air. Itu merupakan hal yang sangat mudah dilakukan untuk membuat telur matang. Akan tetapi hal tersebut memiliki banyak kelemahan, antara lain kita tidak tau kapan telur itu akan matang dan terkadang telur akan tidak matang dengan sempurna. Selain itu hal yang tidak disadari bahwa telur yang matang dengan direbus untuk membuka telur akan sulit dikarenakan kulit telur akan menempel dengan daging telur.

Dalam hal nutrisi, telur sangat susah ditandingi, itu dikarenakan telur dikategorikan sebagai "superfood" alias makanan super. Telur memberikan banyak manfaat bagi tubuh antara lain sumber protein tinggi. Mengawali pagi hari dengan mengkonsumsi telur bisa menjadi pilihan utama, karena dengan sarapan dengan telur bisa menahan rasa kenyang lebih lama.

Dari hal diatas maka peneliti terinspirasi membuat suatu alat yang bisa mematangkan telur dengan cara praktis dan bersifat otomatis. Dengan sistem pengkukusan untuk mematangkan telur, itu merupakan hal sangat tepat. Karena dengan proses pengkukusan selain telur matang lebih cepat dan hasilnya kulit telur tidak menempel pada daging. Oleh karena itu untuk membuka telur lebih mudah. Egg Boiler (Pengkukus Telur Otomatis) 
merupakan salah satu alat yang inovatif dalam proses pematangan telur dan dimana termasuk dalam produk teknologi tepat guna. Alat Egg Boiler tidak menggunakan kompor akan tetapi sumber energi dari listrik. Mengunakan elemen pemanas sebagai sumber panas. Dilengkapi dengan sensor panas (thermostat) yang nantinya akan di hubungkan dengan plat logam, untuk mendeteksi panas dari elemen pemanas tersebut.

\section{Media Pembelajaran}

Kata media berasal dari bahasa latin yang merupakan bentuk jamak dari kata medius yang secara harfiah berarti perantara atau pengantar. Gerlanch \& Ely (dalam Azhar, 2002) mengatakan bahwa media secara garis besar adalah manusia, materi, atau kejadian yang membangun kondisi yang membuat siswa mampu memperoleh pengetahuan keetrampilan, atau sikaf. Dalam pengertian ini, guru, buku teks, dan lingkungan sekolah merupakan media. Secara lebih khusus, pengertian media dalam proses belajar mengajar cenderung diartikan sebagai alat-alat grafis, photografis, atauelektronis untuk menangkap, memperoses, dan menyusun kembali informasi visual atau verbal.

Istilah "media" bahkan sering dikaitkan atau dipergantikan dengan kata "teknologi" yang berasal dari kata latin tekne (Bahasa Inggris art) dan logos (Bahasa Indonesia "ilmu). Menurut Webster (dalam Azhar, 2002: 5), "art" adalah keterampilan (skill) yang diperoleh lewat pengalaman, studi dan observasi. Dengan demikian, teknologi tidak lebih dari suatu ilmu yang membahas tentang keterampilan yang diperoleh lewat pengalaman, studi, dan observasi

Dalam suatu proses belajar mengajar, ada dua unsur yang amat penting adalah metode mengajar dan media pembelajaran. Kedua aspek ini saling berkaitan. Pemilihan salah satu metode mengajar tertentu akan mempengaruhi jenis media pembelajaran yang sesuai, meskipun masih ada berbagai aspek lain yang harus diperhatikan dalam memilih media, antara lain tujuan pembelajaran, jenis tugas dan respon yang diharapkan siswa kuasai setelah pembelajaran belangsung. Hamalik (dalam Azhar, 2002: 15) mengemukakan bahwa pemakaian media pembelajaran dalam proses belajar mengajar dapat membangkitkan keinginan dan minat yang baru, membangkitkan motivasi dan rangsangan kengiatan belajar, dan bahwakan membawa pengaruhpengaruh psikologis terhadap siswa serta sangat membantu keefektifan proses belajar mengajar

\section{Teknologi Tepat Guna}

Teknologi tepat guna merupakan teknologi yang dirancang dan dikembangkan berdasarkan pada aspekaspek lingkungan, sosial, budaya, ekonomi, dan etika masyarakat pengguna. Hemat sumber daya, minim dampak polutif, mudah penggunaan dan perawatannya merupakan bagian yang menjadi perhatian. Karya rekayasa inovatif dibuat untuk mempermudah dan meningkatkan efisiensi dan efektifitas dalam pembuatan produk, di antaranya berupa produk pengolahan hasil pertanian, perkebunan, perikanan, limbah perkebunan yang semua itu merupakan bagian solusi guna berproduksi. (Sumber: http://id.m.wikipedia.org/wiki/

Teknologi Tepat Guna).

\section{METODE}

Penelitian ini dilakukan dengan menggunakan metode Penelitian dan Pengembangan (research and development) dalam bidang pendidikan. Metode penelitian dan pengembangan adalah metode penelitian yang digunakan untuk menghasilkan produk tertentu, dan menguji keefektifan produk tersebut. Untuk dapat menghasilkan produk digunakan penelitian yang bersifat analisis kebutuhan (Sugiono, 2009 : 297).

Pada penelitian ini langkah-langkah penelitian dan pengembangan dimulai dari tahapan Potensi Masalah sampai dengan tahapan Ujicoba Produk. Pada penelitian ini yang disesuaikan dengan rumusan masalah yang telah dibuat, yaitu membuatan Prototipe Egg Boiler sebagai media pembelajaran dan tidak akan memproduksi secara masal. Maksud dari produksi masal itu berkaitan dengan bidang bisnis dan untuk memproduksi masal, maka 
peneliti perlu bekerja sama dengan perusahaan, menurut Sugiono, 2009: 311.

\section{Potensi dan Masalah}

Penelitian dapat berangkat dari adanya potensi atau masalah (Sugiono, 2009: 298). Berdasarkan hasil observasi, pada kelas XI MIA SMA Negeri 4 Singaraja, disanalah peneliti melaksanakan praktikum PPL-REAL selama 3 bulan. Selama melaksanakan kegiatan PPL-Real peneliti menemukan banyak kendala yang dihadapi, khususnya dalam bidang menyampaikan suatu materi atau proses pembelajaran. Sesuai dengan Standar Kompetensi yang telah ditentukan, dimana siswa akan dituntut agar bisa membuat sesuatu projek yang akan digunakan sebagai modal untuk berwirasausaha. Projek yang dibuat sesuai dengan materi pokok yang didapatkan pada semester tersebut. Untuk semester genap nanti materi pokok yang akan dibahas yaitu Teknologi Tepat Guna. Jadi karena siswa di SMA Negeri 4 Singaraja kebanyakan memiliki dasar yang lemah di bidang elektronika dan untuk membuat suatu projek, rasanya itu sangat membebani siswa tersebut. Dari potensi dan masalah yang ditemukan, peneliti mencoba untuk mengembangkan suatu media pembelajaran sebagai pendukung dalam pembelajaran pada materi Teknologi Tepat Guna.

\section{Pengumpulan Data}

Berdasarkan hasil observasi dan wawancara, ditemukan informasi bahwa siswa di SMA Negeri 4 Singaraja memiliki potensi dalam bidang Rekayasa pada mata pelajaran Prakarya dan Kewirausahaan. Namun dengan masalah yang ditemukan bahwa siswa tidak dapat mengembangkan potensi dalam pembelajaran Teknologi Tepat Guna dengan mata pelajaran Prakarya dan Kewirausahaan, serta tidak adanya media pendukung pembelajaran di sekolah, jadi dilakukan Pengembangan Prototipe Egg Boiler sebagai Media Pembelajaran Prakarya dan Kewirausahaan untuk materi Teknologi Tepat Guna di SMA Negeri 4 Singaraja.

\section{Desain Produk}

Perencanaan desain produk merupakan gambaran awal Prototipe Egg Boiler dari yang akan dibuat. Dibawah ini merupakan gambar 1. Desaian awal Prototipe Egg Boiler.

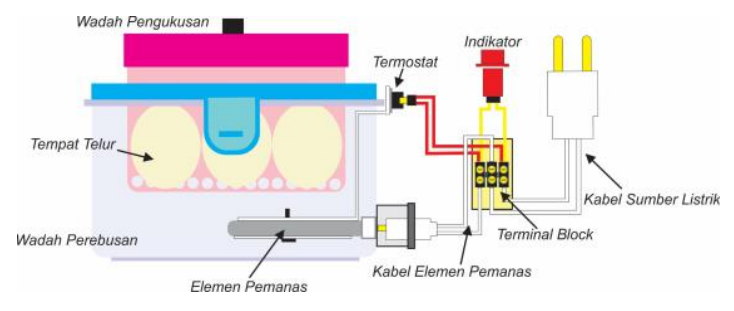

Gambar 1. Desain Prototipe

(Sumber: Penelitian, 2017)

\section{Validasi Desain}

Hasil rancangan produk berupa Prototipe Egg Boiler kemudian divalidasi yang berupa media pembelajaran. Ditentukan sejumlah validator sebelum penelitian dilaksanakan. Karena akan melakukan penelitian tentang media pembelajaran Prototipe Egg Boiler maka validator dipilih berdasarkan orang-orang yang memiliki pengetahuan, pengalaman, dan pemahaman di bidang tersebut.

Untuk menguji validasi konstruksi, dapat digunakan pendapat dari ahli (judgment expert). Dalam hal ini setelah instrumen dikonstruksi tentang aspekaspek yang akan diukur dengan berlandaskan teori tertentu, maka selanjutnya dikonsultasikan dengan ahli (Sugiyono, 2009:125). Pengujian validitas konstrak dilakukan dengan meminta pendapat kepada dosen bidang Media Pembelajaran, serta guru pengampu mata pelajaran Prakarya dan Kewirausahaan di bidang Rekayasa pada kelas XI MIA di SMA Negeri 4 Singaraja.

Pengujian validitas ini dapat dilakukan dengan membandingkan antara isi instrumen dengan materi yang diajarkan (Sugiyono, 2009:129). Pengujian validasi dilakukan dengan meminta pendapat kepada dosen bidang Teknik Elektronika serta guru pengampu mata pelajaran Prakarya dan Kewirausahaan di bidang Rekayasa, dan para siswa kelas XI MIA di SMA Negeri 4 Singaraja. 
Dalam Candiasa (2011: 23-24), mekanisme perhitungan validitas isi menurut Gregory adalah seb

agai berikut.

Validitas Isi $=\frac{D}{A+B+C+D}$

\section{Keterangan :}

$A=$ sel yang menunjukkan ketidak setujuan antara kedua penilai

$\mathrm{B}$ dan $\mathrm{C}=$ sel yang menunjukkan perbedaan pandangan antara penilai

$D=$ sel yang menunjukkan persetujuan yang valid antara kedua Penilai

\section{Revisian Desain}

Setelah hasil produk Prototipe Egg Boiler divalidasi, hasil validasi kemudian didiskusikan dengan validator. Apabila pada saat pelaksanaan validasi Prototipe Egg Boiler ini memperoleh hasil kurang memuaskan dari validator, maka desain produk tersebut akan disempurnakan lagi sehingga tingkat validasi pada produk tersebut meningkat dan dapat dilakukannya penelitian tahap lanjut yaitu uji coba produk.

\section{Uji coba Produk}

Pada tahap II ini produk diuji cobakan pada siswa. Uji coba produk dilakukan dengan melakukan uji coba perorangan, uji coba kelompok kecil, dan uji coba lapangan. Data yang diperoleh kemudian dianalisis dan digunakan untuk memperbaiki/merevisi produk yang dikembangkan. Setelah melalui proses uji coba produk, diharapkan kualitas media yang dikembangkan menjadi lebih baik.

Adapun tahap-tahap yang dilakukan dalam menguji tingkat efektivitas produk sebagai berikut.

\section{Tahap Pertama}

Memberikan tes awal yang disebut pre-test. Pre-test diberikan berupa tes obyektif yang disesuaikan dengan materi yang akan dijadikan bahan pada Prototipe Egg Boiler. Kemudian hasil atau nilai siswa tersebut dikumpulkan dan direkap sesuai identitas siswa. Setelah direkap kemudian data tersebut dianalisa.

\section{Tahap Kedua}

Siswa diberikan kesempatan untuk melakukan kegiatan praktikum secara berkelompok dengan menggunakan Prototipe Egg Boiler yang telah dikembangkan sebelumnya.

\section{Tahap Tiga}

Kegiatan yang dilakukan dengan memberikan tes yang sama dengan tahap satu. Kegiatan tes ini di sebut juga dengan post-test. Setelah siswa diberikan tes hasil atau nilai siswa tersebut dikumpulkan dan direkap sesuai identitas siswa. Setelah direkap kemudian data tersebut dianalisis.

Teknik Analisa data pada tahap ini adalah dilakukan dengan menggunakan analisis Content Validity Ratio (CVR). Menurut Lawshe dalam (Satrisman, 2013:30) setiap butir soal yang dianggap penting oleh lebih dari setengah validator, memiliki tingkatan validasi isi yang baik. Oleh karena itu analisis CVR dirumuskan dengan persamaan berikut.

CVR $=\frac{\left(n e-\frac{N}{2}\right)}{\frac{N}{2}}$

(Sumber: Lawshe dalam Satrisman, 2013:30)

$\mathrm{Ne} \quad$ : Jumlah siswa yang menyatakan butir soal penting

$\mathrm{N} \quad$ : Jumlah siswa

Hasil rumusan dari Lawshe (1975) ini adalah:

(1) Jika tanggapan siswa yang menyatakan setuju kurang dari setengah dari jumlah total siswa yang menanggapi maka CVR bernilai negatif.

(2) Jika tanggapan siswa yang menyatakan setuju tepat setengah dari jumlah total siswa yang menanggapi maka CVR bernilai nol.

(3) Jika tanggapan siswa yang menyatakan setuju lebih dari setengah jumlah total siswa yang menanggapi maka nilai CVR berada antara 0 sampai dengan 0,99 . 
(4) Jika seluruh tanggapan siswa menyatakan setuju maka nilai CVR adalah 1, 00 .

Setelah mengidentifikasi sub pertanyaan pada angket dengan menggunkan CVR, CVI dihitung untuk menghitung keseluruhan jumlah sub pertanyaan. Secara sederhana CVI merupakan rata-rata dari nilai CVR untuk sub pertanyaan yang dijawab Ya.

$$
C V 1=\frac{\text { Total CVR }}{\text { Jumlah sub pertanyaan }}
$$

(Sumber: Lawshe dalam Satrisman, 2013:31)

\section{HASIL DAN PEMBAHASAN}

Desain produk merupakan wujud dari rancangan media pembelajaran berupa Prototipe Egg Boiler. Tampilan Prototipe Egg Boiler dapat dilihat pada Gambar 2.

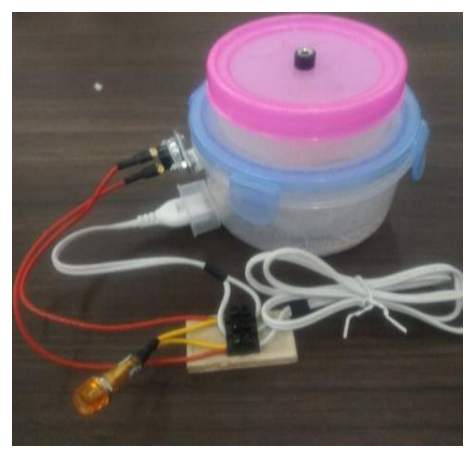

Gambar 2. Prototipe Egg Boiler (Sumber: Penelitian, 2017)

Tabel 1. Hasil Nilai Validasi

\begin{tabular}{cccc}
\hline No & Penilaian & Nilai Validasi & Kategori \\
\hline 1 & Ahli Media & 0.75 & Tinggi \\
2 & Ahli Isi & 0.81 & Sangat Tinggi \\
\hline
\end{tabular}

\section{Revisian Desain}

Berdasarkan penilaian dari uji validasi desain yang ditinjau dari 2 (dua) kriteria penilaian, produk ini memperoleh tingkat pencapaian validasi konstrak/media 0,75 dan validasi isi 0,81 yang termasuk dalam kategori Tinggi dan Sangat Tinggi. Sehingga dari segi desain produk Prototipe Egg Boiler ini tidak perlu direvisi.

\section{Penelitian Tahap II}

Uji coba produk dinilai dari 4 aspek, antara lain; (1) kualitas isi dan tujuan; (2) kualitas pembelajaran; (3) kualitas teknis, dan (4) kemanfaatan, yang dilakukan dengan melakukan uji coba perorangan, uji kelompok kecil, dan uji coba lapangan.

\section{Uji Coba Perorangan}

Media Protitipe Egg Boiler telah melewati hasil validasi desain, selanjutnya akan melalui tahap lanjut. Tahap lanjut tersebut dilakukan dengan uji coba perorangan dengan siswa kelas XI MIA di SMA Negeri 4 Singaraja sebanyak 3 (tiga) orang dengan mewakili karakteristik populasi sasaran. Berdasarkan dari uji coba perorangan, total nilai CVR yang diperoleh sebesar 18,65 kemudian dimasukan dalam rumus CV1. 
$C V 1=\frac{18,65}{20}=0,93$

Tingkat pencapaian CV1 pada uji coba peorangan yang ditinjau dari 4 (empat) aspek sebesar 0, 93. Komentar/saran umum dari ketiga subjek dapat dianalisa bahwa tidak ada saran revisi, sehingga Prototipe Egg Boiler ini dapat diuji cobakan pada tahap selanjutnya yaitu uji coba kelompok kecil.

\section{Uji Coba Kelompok Kecil}

Uji coba kelompok kecil dilakukan kepada siswa kelas XI MIA 4 di SMA Singaraja sebanyak 8 (delapan) orang dengan mewakili karakteristik populasi sasaran. Berdasarkan hasil uji coba kelompok kecil, total nilai CVR yang diperoleh sebesar 17,25 , kemudian dihitung dalam rumus $\mathrm{CV} 1$.

$C V 1=\frac{14,25}{20}=0,71$

Tingkat pencapaian CV1 pada uji coba kelompok kecil yang ditinjau dari 4 (empat) aspek sebesar 0, 71. Komentar/ saran umum dari kedelapan subjek tersebut dapat dianalisis bahwa tidak ada saran revisi, sehingga Prototipe Egg Boiler ini dapat diuji cobakan pada tahap selanjutnya yaitu uji coba kelompok besar.

\section{Uji Coba Lapangan}

Uji coba lapangan dilakukan kepada siswa kelas XI MIA 4 di SMA Negeri 4 Singaraja sebanyak 40 orang dengan mewakili karakteristik populasi sasaran. Berdasarkan hasil uji coba lapangan, maka total nilai CVR yang diperoleh sebesar 2,46, kemudian dihitung dalam rumus CV1.

$C V 1=\frac{2,46}{3}=0,82$

Tingkat pencapaian CV1 pada uji coba peorangan yang ditinjau dari 4 (empat) aspek sebesar 0,82. Dari uji coba produk yang dilakukan dengan uji coba perorangan, uji coba kelompok kecil, dan uji coba lapangan dapat dijelasnya pada Gambar 3.

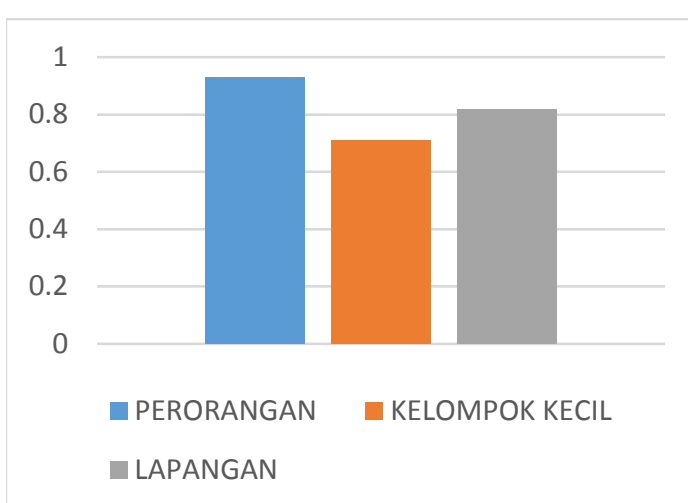

Gambar 3 Hasil Uji Coba Produk (Sumber: Penelitian, 2017)

\section{SIMPULAN}

Dalam perancangan Prototipe Egg Boiler adapun beberapa langkah - langkah penelitian yang dilakukan, yaitu Potensi Masalah, Pengumpulan Data, Desain Produk, Validasi Desain, Revisian Desain, dan Uji Coba Produk. Prototipe Egg Boiler telah diuji vadititas media dengan nilai sebesar 0,75 dalam kategori tinggi. Uji validasi isi dengan nilai sebesar 0,81 dalam kategori sangat tinggi. Sedangkan hasil uji coba perorangan dengan nilai sebesar 0.93 , uji coba kelompok kecil dengan nilai sebesar 0.71 , dan uji coba lapangan dengan nilai sebesar 0.82. Pada uji coba lapangan juga dilakukan dengan menganalisis nilai dari kegiatan praktikum, nilai yang diperoleh 89.75 dikategorikan dengan hasil belajar tinggi. Prototipe Egg Boiler mudah digunakan oleh siswa, ini terlihat perolehan nilai pre-test sebesar 66.5 dikategorikan dengan hasil belajar sedang dan nilai posttest 87.7 dapat dikategorikan dengan hasil belajar tinggi. Sehingga Pototipe Egg Boiler yang telah dikembangkan sangat membantu siswa dalam memahami materi dan praktikum mata pelajaran Prakarya dan Kewirausahaan untuk materi Teknologi Tepat Guna pada kelas XI MIA di SMA Negeri 4 Singaraja.

Berdasarkan simpulan yang telah dipaparkan dalam penelitian ini, maka dapat diajukan saran sebagai berikut.

1. Bagi siswa, diharapkan penelitian ini dapat dijadikan sebagai media pembelajaran dalam pendukung proses 
pembelajaran pada mata pelajaran Prakarya dan Kewirausahaan.

2. Bagi guru, diharapkan hasil penelitian yang berupa media pembelajaran ini dapat membantu terjadinya proses pembelajaran dan dapat membantu pemahaman siswa pada mata pelajaran Prakarya dan Kewirausahan.

3. Bagi peneliti lain, hasil penelitian pengembangan ini dapat menjadi acuan dalam melakukan penelitian dan dengan bergantinya kurikulum baru, dimungkinkan Prototipe Egg Boiler ini harus dikembangkan sesuai dengan kurikulum yang digunakan.

\section{DAFTAR PUSTAKA}

Admin. 2016. Teknologi Tepat Guna. http://id.m.wikipedia.org/wiki/ Teknologi Tepat Guna. (diakses pada Novemner 2016)

Azhar Arsyad. 2002. Media Pembelajaran. Jakarta: Rajawali

Candiasa, I Made. 2011. Pengujian Instrumen Penelitian Disertai Aplikasi ITEMAN dan BIGSTEPS. Singaraja: UNDIKSHA PRESS
Satrisman, Adi. 2013. Analisis Soal Ujian Nasional Kimia SMA Tahun 2013 Berdasarkan Taksonomi Bloom Dua Dimensi Universitas Pendidikan Indonesia. Tersedia pada: https://www.google.co.id/url?sa=t\&rct $=\mathrm{j} \& \mathrm{q}=\&$ esrc $=$ s\&source $=$ web \&cd $=1 \& \mathrm{ca}$ $\mathrm{d}=$ rja\&uact=8\&ved=0ahUKEwim3LLV 57DNAhWFvY8KHZXWBEsQFggbM AA\&url=http\%3A\%2F\%2Frepository.u pi.edu\%2F2236\%2F6\%2FS KIM 070 6527 Chapter3.pdf\&usg=AFQjCNFN $\mathrm{E}-$

KYyTMbeHJN4SAJlaiwGQI1Og\&sig2 =2oUhvw7O283AulLe6Zz93Q .Diakses pada 01 Juli 2017.

Sugiono. 2009. Metode Penelitian Kuantitatif, Kualitatif dan R\&D. Bandung: CV. Alfabeta.

Yudo, Nugroho. 2010. PROTOTYPING. Tersedia

pada:

https://www.scribd.com /doc/29879394/1-PROTOTYPING. Diakses pada : 17 April 2017 